\title{
Investigating the Nano-Films Effect on Physical, Mechanical Properties, Chemical Changes, and Microbial Load Contamination of White Button Mushrooms during Storage
}

\author{
Sami Rokayya ${ }^{1, *}$, Ebtihal Khojah ${ }^{1}$, Abeer Elhakem ${ }^{2}$, Nada Benajiba ${ }^{3}$, Murthy Chavali ${ }^{4}{ }^{\oplus}$, Kambhampati Vivek $^{5}$, \\ Abdullah Iqbal ${ }^{6}$ and Mahmoud Helal ${ }^{7}$ \\ 1 Department of Food Science and Nutrition, College of Sciences, Taif University, P.O. Box 11099, Taif 21944, \\ Saudi Arabia; eykhojah@tu.edu.sa \\ 2 Department of Biology, College of Science and Humanities in Al-Kharj, Prince Sattam Bin Abdulaziz \\ University, Al-Kharj 11942, Saudi Arabia; a.elhakem@psau.edu.sa \\ 3 Department of Basic Health Sciences, Deanship of Preparatory Year, Princess Nourah Bint Abdulrahman \\ University, P.O. Box 84428, Riyadh 11671, Saudi Arabia; nabenajiba@pnu.edu.sa \\ 4 Materials Department, NTRC-MCETRC and Aarshanano Composite Technologies Pvt. Ltd., Tenali, Guntur \\ District, Andhra Pradesh 522201, India; chavalim@gmail.com \\ 5 Food Technology and Management, Indian Institute of Plantation Management Bengaluru, Bengaluru, \\ Karnataka 560056, India; vivek.tezu@gmail.com \\ 6 Department of Food Technology and Rural Industries, Bangladesh Agricultural University, \\ Mymensingh 2202, Bangladesh; iqbal21155@bau.edu.bd \\ 7 Department of Mechanical Engineering, Faculty of Engineering, Taif University, P.O. Box 11099, Taif 21944, \\ Saudi Arabia; mo.helal@tu.edu.sa \\ * Correspondence: rokayya.d@tu.edu.sa
}

\section{check for}

updates

Citation: Rokayya, S.; Khojah, E.; Elhakem, A.; Benajiba, N.; Chavali, M.; Vivek, K.; Iqbal, A.; Helal, M. Investigating the Nano-Films Effect on Physical, Mechanical Properties, Chemical Changes, and Microbial Load Contamination of White Button Mushrooms during Storage. Coatings 2021, 11, 44. https://doi.org/ 10.3390/coatings11010044

Received: 15 December 2020 Accepted: 29 December 2020 Published: 4 January 2021

Publisher's Note: MDPI stays neutral with regard to jurisdictional clai$\mathrm{ms}$ in published maps and institutional affiliations.

Copyright: (C) 2021 by the authors. Licensee MDPI, Basel, Switzerland. This article is an open access article distributed under the terms and conditions of the Creative Commons Attribution (CC BY) license (https:// creativecommons.org/licenses/by/ $4.0 /)$.

\begin{abstract}
Nutrient-rich edible white button mushrooms were coated with Chitosan (1\%), Chitosan/nanosilica, and Chitosan/nano-titanium and then stored at $4{ }^{\circ} \mathrm{C}$ to investigate the physical, mechanical properties, chemical changes, and microbial load contamination at an interval of 3 days up to a 12 days storage period. It was noticed that Chitosan/nano-titanium and Chitosan/nano-silica preserved the weight loss percentages as $11.80 \%$ and $12.69 \%$, respectively. Treatment with Chitosan/nano-silica coating was found to have positive impacts on the overall color parameters. Both of the nanocoating films enhanced headspace gas compositions and firmness. Chitosan/nano-silica samples recorded the least electrolyte leakage value $(24.44 \%)$, as low oxygen gas concentration can reduce the respiration rate, weight loss, and cap opening. Chitosan/nano-titanium treatment showed the lowest cap opening value (19.58\%), PPO activity $\left(16.98 \mathrm{mg}^{-1}\right.$ protein), and microbial load contamination (6.12 $\log$ CFU/g) at the end of the whole storage period, suggesting that nano-films are a promising preservation method for prolonging the white button mushroom's shelf-life.
\end{abstract}

Keywords: white button mushroom; nano-films; preservation; microbial load; storage

\section{Introduction}

Agaricus bisporus is a fast-growing fungus that is widely known as the white button mushroom. Button mushrooms are consumed worldwide due to their high nutritional value low carbohydrate and fats with high protein, amino acids, polysaccharides, minerals, multivitamins, (e.g., thiamine, ergosterol, niacin, riboflavin, and ascorbic acid) and phytochemical components (e.g., sterols, polyphenolics, and terpenes) [1]. The unique flavor, taste, texture, and hedonic palatability make it one of the most popular edible mushrooms [2,3]. In addition, its biological activities are very beneficialdue to their resulting nutraceutical and pharmaceutical characteristics [4]. Mushrooms are highly perishable with a short shelf-life due to their high water content, cuticle formation absence, and respiration rate [5]. Open umbrellas, wrinkles, and browning caps are significant factors that limit customer overall acceptability and quality which are caused by the substance 
phenolic oxidations such as polyphenol oxidase (PPO) activity and which lead to mushroom senescence [6]. A number of postharvest treatments for button mushrooms has been observed for browning reduction and quality preservation such as those with glycine betaine, citric acid, brassinolide, sodium metabisulphite, 4-methoxy cinnamic acid, and hydrogen peroxide $[7,8]$. Many techniques have been applied to prolong their shelf-life, such as nitric oxide, brassinolide, cinnamaldehyde fumigation, $\mathrm{O}_{2}$ and $\mathrm{CO}_{2}(15: 050 \%)$, and UV-C treatments $[9,10]$. Meanwhile, various physical methods have been applied such as moisture absorbers, irradiation, light treatments, chilling, and atmospheric packaging control for extending the shelf-life of mushrooms [11-14]. Wei et al. [15] applied polyethylene, silicon windows, and polyvinyl chloride as effective packaging materials on pine mushroom preservations. Application of Aloe vera gel over the surface of the button mushroom created a barrier to oxygen and carbon dioxide, which in turn delayed browning, softening, microbial load, and weight loss [16]. Jiang et al. [17], applied chitosan with glucose complex on shiitake mushrooms during 16 days of storage which maintained firmness, the respiration rate, and pseudomonads, yeasts, and molds contaminations. Liu et al. [18] applied gallic acid grafted chitosan films, which better maintained the postharvest quality of button mushrooms compared with the commercial polyethylene films. Gholami et al. [19] reported that the best atmosphere packaging for button mushrooms preservation is $15 \%$ oxygen and $5 \%$ carbon dioxide with the combination of chitosan and nanopackaging films. Nano-films such as silica and titanium dioxides are considered to be safe with low concentrations according to the US Food and Drug Administration (US-FDA) [20].

Limited studies have been reported on the effects of nano-films coating treatments on white button mushrooms during cold storage. The novelty of this study is to apply nanocomposite materials such as nano-silica and titanium with the addition of chitosan to prolong the shelf life of white mushrooms (Agaricus bisporus) by evaluating their physical, mechanical properties, chemical changes, and microbial load contamination.

\section{Materials and Methods}

\subsection{Materials and Sample Treatments}

Fresh mushroom samples were purchased from the College of Science, Taif University, Kingdom of Saudi Arabia (KSA). Mushroom samples were selected in uniform sizes of 30 to $40 \mathrm{~mm}$ in diameter, with no sign of mechanical damage and microbial infections. Any bruised or diseased mushrooms were discarded and chilled at $4{ }^{\circ} \mathrm{C}$ in darkness for determinations. Materials such as chitosan ( $85 \%$ deacetylation), nano-silica, and nanotitanium $(15 \mathrm{~nm})$ as well as the other chemicals were purchased from Shanghai, China or from Sigma-Aldrich, St. Louis, MO, USA. The amount of deposited solution was $450 \mathrm{~mL}$, the nozzle size was $20-40 \mu \mathrm{L}$, and the pressure was 3-14 kg. The distance between the torch nozzle exit and the external feeding tube was $80 \mathrm{~mm}$ while the distance between the torch nozzle exit and substrate was $400 \mathrm{~mm}$ [21]. Coating solutions were prepared by dissolving $1 \%$ chitosan ( $85 \%$ deacetylation) in $1 \%$ acetic acid solution and $0.5 \%$ glycerol in deionized water while stirring overnight, during which the acidity was adjusted to 6.0 with sodium hydroxide solution to prepare Chitosan coating treatment. Chitosan/nano-silica and Chitosan/nano-titanium were prepared by dissolving $1 \%$ of nano-silica and nanotitanium $(15 \mathrm{~nm})$ in chitosan solution, respectively. The coating treatments were applied on mushrooms compared with the control sample, which was coated with deionized water. Whole mushrooms groups were spray-coated with various solutions for $3 \mathrm{~min}$ and then allowed to air-dry for another $30 \mathrm{~min}$ by using an industrial fan at room temperature with a relative humidity of $80-85 \%$. Mushroom samples were packaged into polyethylene bags and stored at $4{ }^{\circ} \mathrm{C}$ for studying physical properties, mechanical properties, chemical changes, and microbial load contamination. Three replicates for each treatment were performed for a storage period of 3 days to 12 days. 


\subsection{Analyses}

2.2.1. Weight Loss, Acidity, and Total Soluble Solids Concentrations

Weight loss (WL) was observed by weighing the samples during the storage period and calculated as a percentage according to Equation (1):

$$
\text { Weightloss }(\%)=\left(\frac{W_{0}-W_{t}}{W_{t}}\right) \times 100
$$

where $W_{0}$ is the initial weight, while $W_{t}$ is the weight at a different time $(t=3,6,9$, and 12 days). All samples were measured in triplicate [19].

For the acidity $(\mathrm{pH})$ and total soluble solid concentrations (TSS) determination, mushroom samples were homogenized with $15 \mathrm{~mL}$ of deionized water and filtered using Whatman ${ }^{\circledR}$ grade 40 ashless filter paper purchased from Sigma-Aldrich, Co., Columbia, USA. The $\mathrm{pH}$ and TSS were detected by using a digital $\mathrm{pH}$ meter (Basic $20^{+}$, Crison Instruments, S.A., Barcelona, Spain) and a digital hand-held "pocket" refractometer (Atago $\mathrm{PAL}^{-1}$, Tokyo, Japan), respectively [22].

\subsubsection{Color Investigation Measurements}

The surface color was examined by a colorimeter (CR-400 Chroma Meter, Konica Minolta Sensing, Osaka, Japan) during the 12 day storage duration. In this system $L^{*} a^{*} b^{*}$ coordinates were uniform three-dimensional color spaces, as the $L^{*}$ value represents lightness), the $a^{*}$ value is redness, whereas the $b^{*}$ value is yellowness scales compared with a white plate as a standard under the normal light conditions [23,24].

The color difference $\left(\Delta \mathrm{E}^{*}\right)$ and browning index $(\mathrm{BI})$ were detected according to Equations (2) and (3):

$$
\begin{gathered}
\Delta \mathrm{E}^{*}=\left[\left(L^{*}-L 0\right)^{2}+\left(a^{*}-a 0\right)^{2}+\left(b^{*}-b 0\right)^{2}\right]^{0.5} \\
\mathrm{BI}=\left[(100(\mathrm{x}-0.31)] / 0.172 \text {, where } \mathrm{x}=\left(a^{*}+1.75 L^{*}\right) /\left(5.645 L^{*}+a^{*}-3.012 b^{*}\right)\right.
\end{gathered}
$$

where $L_{0}, a_{0}$, and $b_{0}$ are the initial color values.

\subsubsection{Cap Opening Percentage}

The number of open veil caps of the intact button mushroom stage was detected based on the failure of the veil according to Equation (4) [25]:

$$
\text { Cap opening percentage }(\%)=\left[\left(\mathrm{V}_{\mathrm{t}}-\mathrm{V}_{\mathrm{f}} / \mathrm{V}_{\mathrm{i}}\right) \times 100 \%\right]
$$

where $V_{t}=$ Total mushroom numbers and $V_{f}=$ Number of the open veil.

\subsubsection{Firmness and Electrolyte Leakage Rate}

The firmness (F Max) was measured as the first maximum force peak applied by a food textural analyzer (TA-XT2i; Stable Micro Systems Ltd., Godalming, Surrey, UK) using a $4 \mathrm{~mm}$ diameter cylindrical probe in compression mode with a distance of $5 \mathrm{~mm}$ diameter and a speed of $5 \mathrm{~mm} /$ susing a $100 \mathrm{~N}$ cell load on 15 replications for each coating treatment. Test Xpert software (v10.11) (ZwickRoell, Kennesaw, GA, USA) was used to perform data analysis [19].

The electrolyte leakage rate of solutions was evaluated by a benchtop laboratory conductivity meter (DDS-307A; Shanghai Boqu Instrument Co., Ltd. Shanghai, China). The mushroom ( $3 \mathrm{~mm}$ thick $\times 1 \mathrm{~mm}$ diameter) was weighed and excised from the top and middle part of the mushroom cap followed by placing it in $40 \mathrm{~mL}$ deionized water in a 100 $\mathrm{mL}$ glass beaker. The electrical conductivity of solutions (C1) was measured. Consequently, we added $25 \mathrm{~mL}$ of deionized water at $100{ }^{\circ} \mathrm{C}$ and kept it in the shaker for $2 \mathrm{~h}$ at 100 cycles/min [26]. The final record (C2) was measured after cooling. The relative electrolyte leakage rate was detected according to Equation (5): 


\subsubsection{Headspace Gas Composition and PPO Activity Analysis}

The mushroom packages for monitoring of $\mathrm{O}_{2}$ and $\mathrm{CO}_{2}$ gases were measured in triplicate for each coating treatment by the gas meter (Oxybaby 6i, WITT Gasetechnik $\mathrm{GmbH}$, Kopenhagen, Germany). A syringe needle was inserted in a septum on the outer surface of the packages for measuring the interior gases every 3 days (for 12 days) [27]. The differences in-between the totality volume of the packages and that of the mushroom samples were calculated for the headspace volume.

Approximately $0.1 \mathrm{~mL}$ of PPO enzyme was blended with $4 \mathrm{~mL}$ of $0.1 \mathrm{~mol} \mathrm{~L}^{-1}$ phosphate buffer (pH 7.0) and $1 \mathrm{~mL}$ of $50 \mathrm{mmol} \mathrm{L}^{-1}$ catechol. Sample extracts were prepared by mixing $2 \mathrm{~g}$ of shredded mushrooms with $7 \mathrm{~mL} 0.05 \mathrm{~mol} / \mathrm{L}$ phosphate buffer solution, adjusting the $\mathrm{pH}$ to (5.0), and then centrifuging (Versati TM Micro, MCV-88, Shanghi, China) for $15 \mathrm{~min}$ to collect the supernatant [28]. PPO activity was measured at $410 \mathrm{~nm}$ and expressed as $\mathrm{U} \mathrm{mg}^{-1}$ protein.

\subsubsection{Microbial Load Contamination}

The total bacterial load was noted at an interval of 3 days up to the total 12 day storage period to detect the antimicrobial effect of the nano-films coating treatments on white button mushrooms. Initial dilutions up to $10^{-6}$ were prepared by weighing $25 \mathrm{~g}$ mushrooms placed into a sterile stomacher bag for $2 \mathrm{~min}$ with $225 \mathrm{~mL}$ of sterile peptone water. Aliquants of $0.1 \mathrm{~mL}$ from each mushroom dilution were transferred into nutrient agar medium at $30^{\circ} \mathrm{C}$ and incubated for 7 days [29]. The colony counts were determined and expressed as $\log \mathrm{CFU} / \mathrm{g}$.

\subsubsection{Statistical Analysis}

The significance test $(p \leq 0.05)$ of nano-films effect on physical properties, mechanical properties, chemical changes, and microbial load contamination of white button mushrooms was done in by the two-way ANOVA for the initial 12 day storage period by using the Statistical Package for Social Sciences (SPSS v9.40, Chicago, IL, USA). The data are expressed as the mean $\pm \mathrm{SD}$.

\section{Results and Dissection}

\subsection{Weight Loss (WL), pH, TSS Changes}

The weight loss percentage for the storage period and nano-films coating treatments in white button mushroom samples is presented as illustrated in Figure 1a. There was an extraordinary increase during the storage period, especially for the control samples after 12 days. The weight can be reduced at a rapid rate due to several factors such as respiration and water transpiration [30]. It was understood that Chitosan/nano-titanium and Chitosan/nano-silica preserved the weight loss percentages of $11.80 \%$ and $12.69 \%$, respectively. Hosseini and Moradinezhad [31] reported similar values on weight loss of button mushroom storage following refrigerated storage and controlling the package atmosphere. Rok et al. [32] established weight loss values by using a chitosan and silicon dioxide nanoparticles coating treatment on blueberry fruits, which capably controlled the weight loss during storage by $3.69 \%$ more than the other films. 


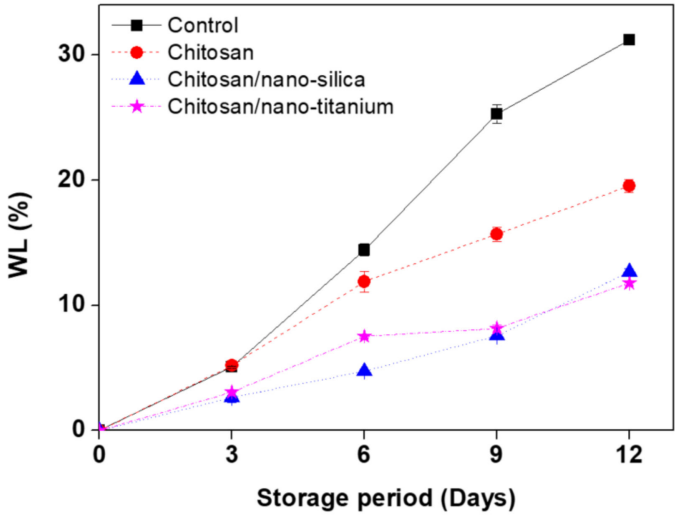

(a)

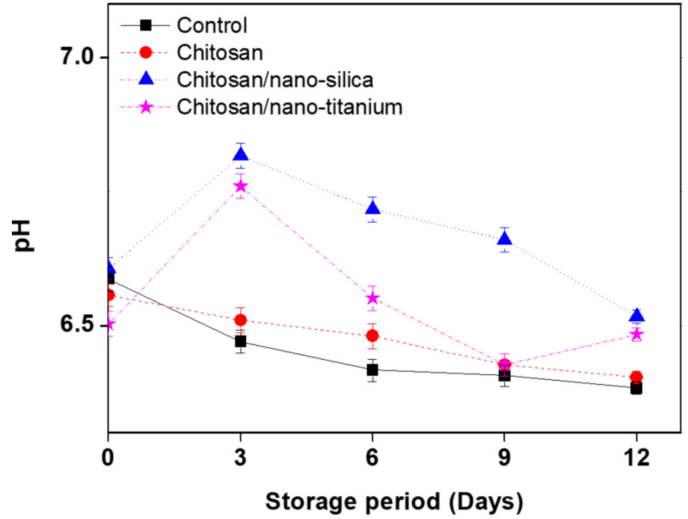

(b)

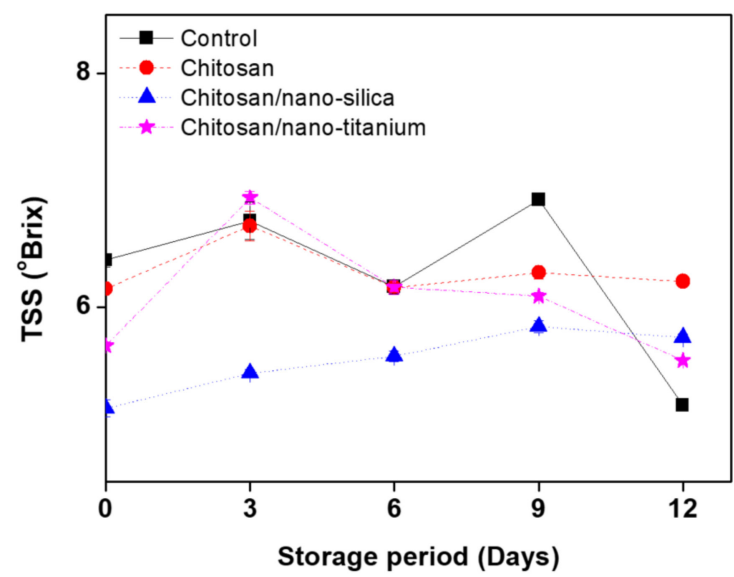

(c)

Figure 1. Effects of nano-films on Weight loss (WL) (a), acidity (pH) (b), and total soluble solid concentrations (TSS) (c) for white button mushrooms during storage at $4^{\circ} \mathrm{C}$ for 12 days. Data are mean $\pm \mathrm{SD}, n=3$.

The $\mathrm{pH}$ is essential throughout the storage period due to its effects on stability and the shelf-life indicator [18]. The $\mathrm{pH}$ changes of the interactions during storage time with the addition of various coating treatments are shown in Figure 1b. The results showed that the values of $\mathrm{pH}$ were different during all storage days, except for the 9 th day. The $\mathrm{pH}$ changes in control samples were ( $\mathrm{pH}$ : 6.38) lower than the coated samples. On the other hand, the Chitosan/nano-titanium treatment ( $\mathrm{pH}$ : 6.48), prevented acidity from being raised until the end of the storage period, followed by Chitosan/nano-silica (pH: 6.52), while the Chitosan coating showed a slight increase in the $\mathrm{pH}$ value compared with the control samples. The use of nano-film coating treatments helped in reducing the respiration rate and keeping the mushroom fresh after harvesting [33].

Total soluble solids concentrations are vital indicators of postharvest as after ripening, the TSS increased at the beginning and then declined during the whole storage period in all the coating treatments, indicating higher respiration rates, senescence, and ripening [33]. The results of TSS in coated-treated mushroom during storage are shown in Figure 1c. The reason for the gradual increase of TSS is the presence of water in the mushroom samples [31]. Chitosan $\left(6.22^{\circ}\right.$ Brix $)$ and Chitosan/nano-silica mushrooms showed the highest results $\left(5.74^{\circ}\right.$ Brix) for TSS compared to the previous report [11].

\subsection{Colour Parameters Changes}

Mushrooms have a short shelf-life due to quality loss expressed by the color changing from white to brown within a short time, as the main considerable parameter for consumer agreement is the color [15].The color parameter changes of white button mushrooms during storage at $4{ }^{\circ} \mathrm{C}$ for 12 days are shown in Table 1 . During storage, the $L^{*}$ value of Chitosan 
and Chitosan/nano-titanium (12.81-13.45) decreased compared with the other mushroom samples. Eissa [34] reported that the lightness decrease was caused by the water-binding capacity due to the coating, which increased the transparency and reduced the mushroom lightness. The higher $a^{*}$ value is an indicator of the enzymatic browning increase during the storage period. This effect was also detected from the increase in the $b^{*}$ value for the control samples from 12.44 at zero days to 24.56 after the 12 days of storage.

Table 1. The values $L^{*}, a^{*}$, and $b^{*}$ from white button mushrooms treated with the control, Chitosan, Chitosan/nano-silica, and Chitosan/nano-titanium stored at $4{ }^{\circ} \mathrm{C}$ for 12 days.

\begin{tabular}{|c|c|c|c|c|c|}
\hline \multicolumn{2}{|c|}{ Storage (Days) } & \multirow{2}{*}{$\frac{\text { Control }}{60.35 \pm 0.22^{a}}$} & \multirow{2}{*}{$\frac{\text { Chitosan }}{53.66 \pm 0.87^{c}}$} & \multirow{2}{*}{$\begin{array}{c}\text { Chitosan/Nano-Silica } \\
38.89 \pm 0.42^{\mathrm{d}}\end{array}$} & \multirow{2}{*}{$\frac{\text { Chitosan/Nano-Titanium }}{56.79 \pm 0.32^{\mathrm{b}}}$} \\
\hline \multirow{5}{*}{$\stackrel{*}{*}$} & 0 & & & & \\
\hline & 3 & $52.92 \pm 1.48^{a}$ & $39.26 \pm 0.44^{\mathrm{c}}$ & $28.53 \pm 0.75^{\mathrm{d}}$ & $46.64 \pm 0.95^{\mathrm{b}}$ \\
\hline & 6 & $26.59 \pm 0.90^{b}$ & $25.70 \pm 1.12^{b}$ & $28.46 \pm 0.70^{a}$ & $25.45 \pm 0.63^{b}$ \\
\hline & 9 & $24.60 \pm 0.28^{b}$ & $23.07 \pm 0.35^{\mathrm{c}}$ & $26.18 \pm 0.60^{\mathrm{a}}$ & $24.80 \pm 0.26^{b}$ \\
\hline & 12 & $19.82 \pm 0.73^{b}$ & $12.81 \pm 0.57^{\mathrm{c}}$ & $22.84 \pm 0.17^{\mathrm{a}}$ & $13.45 \pm 0.15^{\mathrm{c}}$ \\
\hline \multirow{5}{*}{${ }^{*}$} & 0 & $5.78 \pm 0.25^{\mathrm{a}}$ & $5.95 \pm 0.23^{a}$ & $6.29 \pm 0.59^{a}$ & $6.24 \pm 0.85^{\mathrm{a}}$ \\
\hline & 3 & $6.91 \pm 0.20^{\mathrm{a}, \mathrm{b}}$ & $7.64 \pm 0.65^{\mathrm{a}}$ & $6.47 \pm 0.57^{\mathrm{b}}$ & $6.53 \pm 0.14^{b}$ \\
\hline & 6 & $8.58 \pm 0.90^{\mathrm{a}}$ & $7.77 \pm 0.38^{\mathrm{a}, \mathrm{b}}$ & $8.66 \pm 0.17^{\mathrm{a}}$ & $7.07 \pm 0.18^{b}$ \\
\hline & 9 & $8.37 \pm 0.84^{\mathrm{a}}$ & $8.56 \pm 0.93^{\mathrm{a}}$ & $8.56 \pm 0.38^{\mathrm{a}}$ & $8.25 \pm 0.28^{a}$ \\
\hline & 12 & $9.12 \pm 0.34^{b, c}$ & $9.71 \pm 0.65^{b}$ & $11.44 \pm 0.08^{b}$ & $8.40 \pm 0.30^{c}$ \\
\hline \multirow{5}{*}{$\stackrel{*}{\circ}$} & 0 & $12.44 \pm 0.42^{\mathrm{a}}$ & $9.55 \pm 0.35^{c}$ & $10.97 \pm 0.21^{\mathrm{b}}$ & $11.08 \pm 0.16^{b}$ \\
\hline & 3 & $15.75 \pm 0.93^{\mathrm{a}}$ & $14.06 \pm 0.24^{b}$ & $13.02 \pm 0.12^{\mathrm{c}}$ & $12.08 \pm 0.37^{\mathrm{c}}$ \\
\hline & 6 & $16.31 \pm 0.16^{\mathrm{a}}$ & $14.34 \pm 0.33^{b}$ & $14.68 \pm 0.59^{b}$ & $14.80 \pm 0.31^{b}$ \\
\hline & 9 & $17.53 \pm 0.54^{b}$ & $18.09 \pm 0.47^{b}$ & $18.27 \pm 0.34^{\mathrm{b}}$ & $20.14 \pm 0.54^{\mathrm{a}}$ \\
\hline & 12 & $24.56 \pm 0.25^{\mathrm{a}}$ & $20.57 \pm 0.31^{\mathrm{c}}$ & $18.29 \pm 0.10^{\mathrm{d}}$ & $21.46 \pm 0.17^{b}$ \\
\hline
\end{tabular}

${ }^{*}$ Different small letters within the same line; $\mathrm{a}, \mathrm{b}, \mathrm{c}, \mathrm{d}$ mean significant differences between treatments at $p \leq 0.05$. Data are presented as means \pm standard deviation.

Browning is the major postharvest factor which affects the consumer acceptance of mushroom bodies [35]. For that reason, the color difference $\left(\Delta \mathrm{E}^{*}\right)$ and browning index (BI) measurement are crucial for improving potential new preservation strategies. Some positive effects of Chitosan/nano-silica coating treatment were noticed on the overall color parameters of $\left(\Delta \mathrm{E}^{*}\right)$ and $(\mathrm{BI})$ (Figure 2a,b), respectively. Indeed, the presence of nano-silica coating film led to a decrease in $\Delta \mathrm{E}^{*}$ and $\mathrm{BI}$ compared with the other treatments. Referring to the control samples, an increase in $\Delta \mathrm{E}^{*}$ (42.44), a decrease in $L^{*}$ value (19.82), and an increase in BI (363.83) were detected during the 12 days of storage. The modified atmosphere packages may have also managed the browning index and other parameters such as cell membrane and physiological injuries [36].

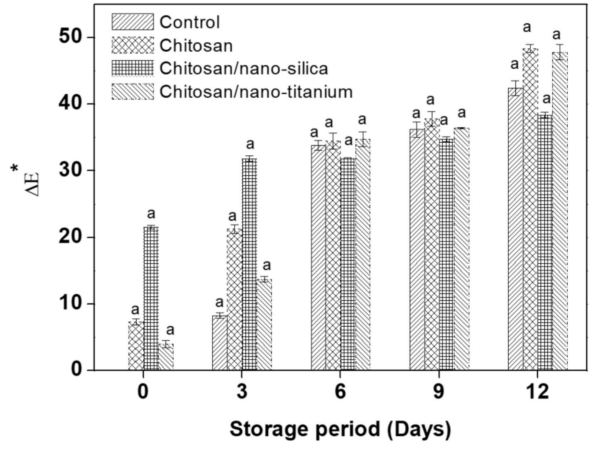

(a)

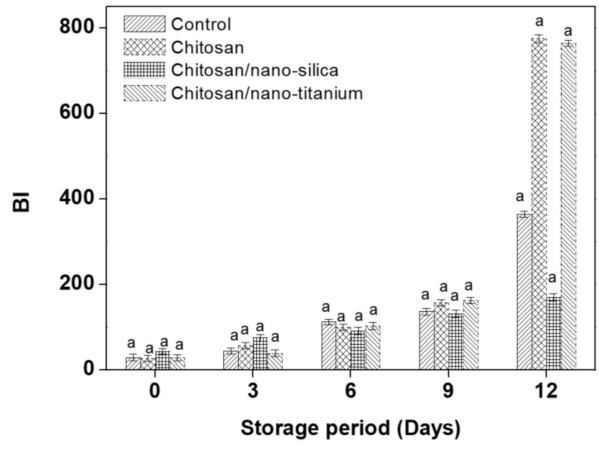

(b)

Figure 2. Effects of nano-films on $\Delta \mathrm{E}^{*}$ (a) and $\mathrm{BI}(\mathbf{b})$ for white button mushrooms during storage at $4{ }^{\circ} \mathrm{C}$ for 12 days. Data are mean $\pm \mathrm{SD}, n=3$; a mean significant differences between treatments at $p \leq 0.05$. 


\subsection{Cap Opening, Firmness, and Electrolyte Leakage Rate}

The cap opening percentage is an index of mushroom ageing and water loss during storage [27]. As shown in Figure 3a, control and Chitosan samples established increases in cap openings $(76.42 \%$ and $46.80 \%$ ), while the Chitosan/nano-titanium treatment showed the lowest value $(19.58 \%)$ by the 12th day of the storage period. This finding of the research work is in line with that of $\mathrm{Oz}$ et al. [27], who studied the postharvest quality and shelf life of mushrooms under the chilling condition. Previous reports in $[15,36]$ were in agreement with the current findings, as low $\mathrm{O}_{2}$ high $\mathrm{CO}_{2}$ concentrations can positively affect the reduction of cap opening and prevent the ripening process.

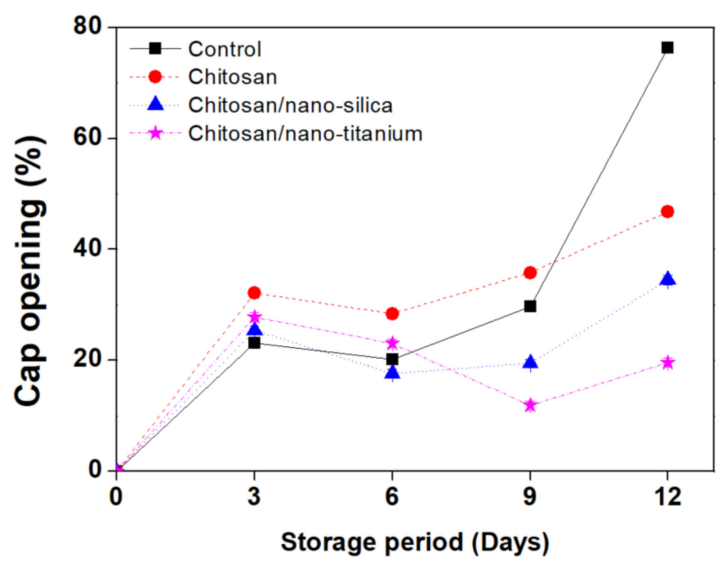

(a)

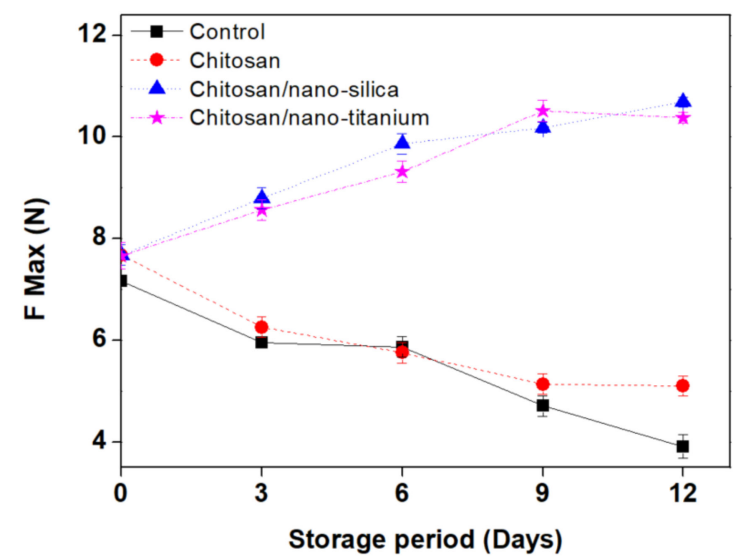

(b)

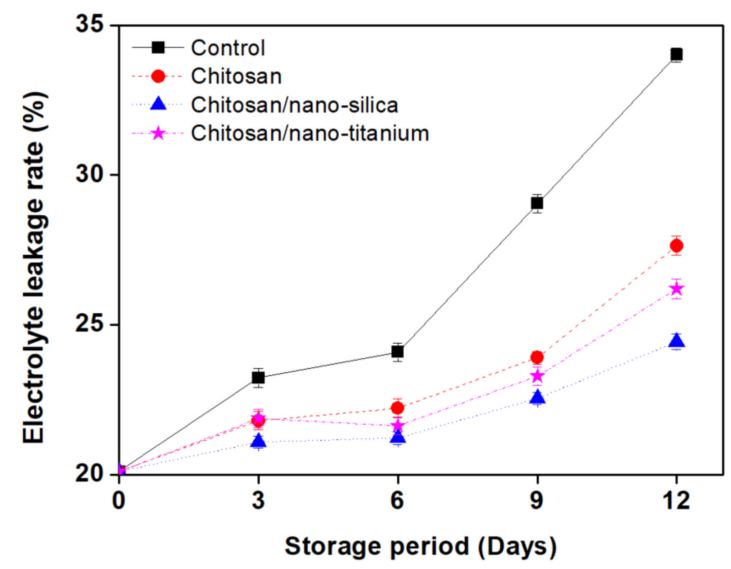

(c)

Figure 3. Effects of nano-films on cap opening (a), F Max (b), and electrolyte leakage rate (c) for white button mushrooms during storage at $4{ }^{\circ} \mathrm{C}$ for 12 days. Data are mean $\pm \mathrm{SD}, n=3$.

Firmness is an important index reflecting the mushroom qualities, as a soft and spongy texture is an indicator for the ageing of mushrooms during the storage period [37]. The effect of various coating treatments on mushroom firmness is presented in Figure $3 \mathrm{~b}$. The mushroom firmness values gradually reduced in control and chitosan during the storage period. The firmness reduction was influenced by several reasons such as polysaccharide and protein degradation, central vacuole disruption, and hyphae shrinkage of the microbial and biochemical processes [38]. Noticeably, Chitosan/nano-titanium and Chitosan/nanosilica mushroom samples had significantly $(p \leq 0.05)$ firmer skin $(10.38-10.69 \mathrm{~N})$ after 12 days of storage, respectively. As a result, nano-films can preserve mushrooms from senescence. Lin et al. [36] reported that mushrooms packaged with the combination of chitosan and silver films showed higher firmness than those packaged with commercial 
ones. Gholami et al. [33] reported similar firmness values using nanocomposite materials on mushroom samples.

Cell membrane permeability stability was detected by using the relative electrolyte leakage as a percentage which increases with the storage period, as seen in Figure 3c. There was a significant difference $(p \leq 0.05)$ between treated and untreated mushroom samples. Chitosan/nano-silica samples $(24.44 \%)$ recorded the least electrolyte leakage value as low oxygen gas concentration can reduce respiration rate, weight loss, and cap opening [39]. Untreated mushrooms showed the highest electrolyte leakage rate (34.01\%). A previously published report [7] had mentioned that the lower membrane integrity value was straight forwardly associated with the mushroom lipid peroxidation activities and browning.

\subsection{Changes in Headspace Gas Compositions and PPO Activity}

As shown in Figure $4 a, b$, it was noticed that the $\mathrm{O}_{2}$ decreased and $\mathrm{CO}_{2}$ increased in all the treatments during the whole storage period. The results of headspace gas compositions were in agreement with the previous reports on mushroom samples $[19,33]$. In this research work, all of the mushroom samples coated with chitosan only depleted with $\mathrm{O}_{2}$, which was achieved during 0 to 6 days of storage $(21.02 \%-10.08 \%)$, then a slight production of $\mathrm{O}_{2}$ occurred afterwards $\left(5.58 \%\right.$ ) on day 12 , while $\mathrm{CO}_{2}$ concentration (5.58\%) was similar to the control at the end of the storage period. Control samples established the highest rate for $\mathrm{O}_{2}$ concentration, which indicated that the increased surface area can lead to a higher respiration rate compared with coating treatments. The $\mathrm{CO}_{2}$ concentration around mushroom samples in Chitosan/nano-titanium coating treatment undoubtedly increased $(9.43 \%)$ followed by Chitosan/nano-silica $(7.30 \%)$ on the third day due to the respiration process. Ban et al. [40] achieved the same results for gas composition, asthe $\mathrm{CO}_{2}$ concentration can be raised sharply after a few hours of post-harvest. The rates of $\mathrm{CO}_{2}$ production and $\mathrm{O}_{2}$ depletion provided by Chitosan/nano-silica samples were better than these gases through Chitosan/nano-titanium and Chitosan treatments at the end of the storage time. Cliffe-Byrnes and O'Beirne, [41] reported that the $\mathrm{O}_{2}$ level should not be lower than $2 \%$ to avoid anaerobic respiration, which can cause tissue breakdown and off-flavors. As a result of this, nano-coating films achieved positive effects on headspace gas compositions.

As seen in Figure 4c, PPO activity is responsible for the enzymatic browning during the storage period. Control mushroom samples significantly $(p \leq 0.05)$ progressively increased (44.38 $\mathrm{mg}^{-1}$ protein) compared with coated samples. At the end of the storage period, Chitosan/nano-titanium samples were the lowest values $\left(16.98 \mathrm{mg}^{-1}\right.$ protein) compared with Chitosan/nano-silica mushrooms (24.31 $\mathrm{mg}^{-1}$ protein). Parallel research works suggested that coating can reduce the contact in-between the PPO enzyme and its substrates due to the phenolic oxidation caused by polyphenol oxidase activity $[15,22]$. 


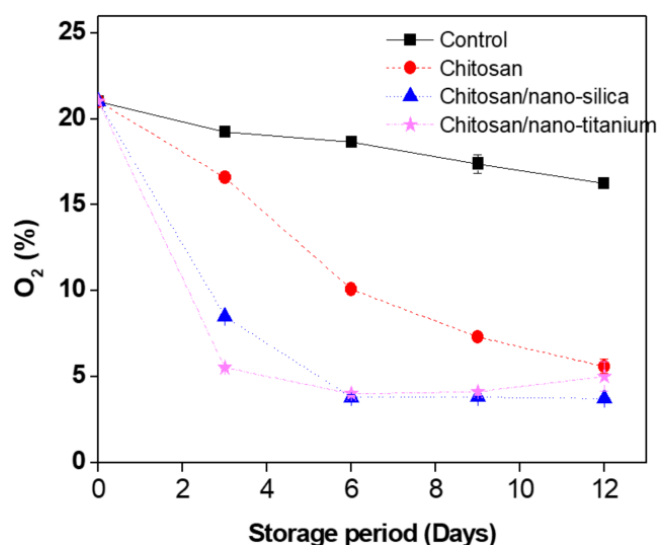

(a)

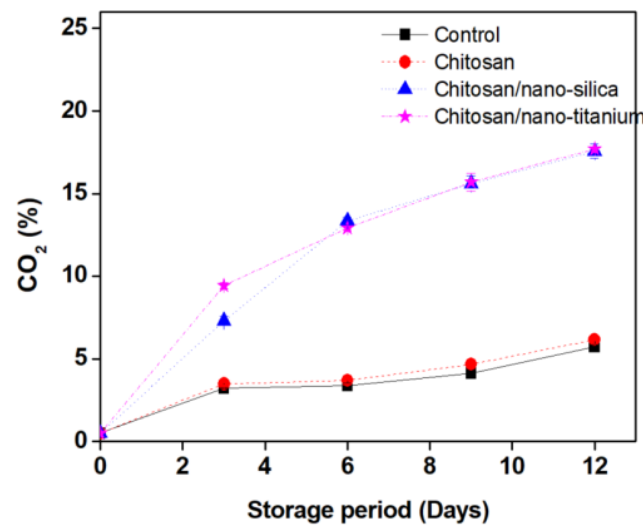

(b)

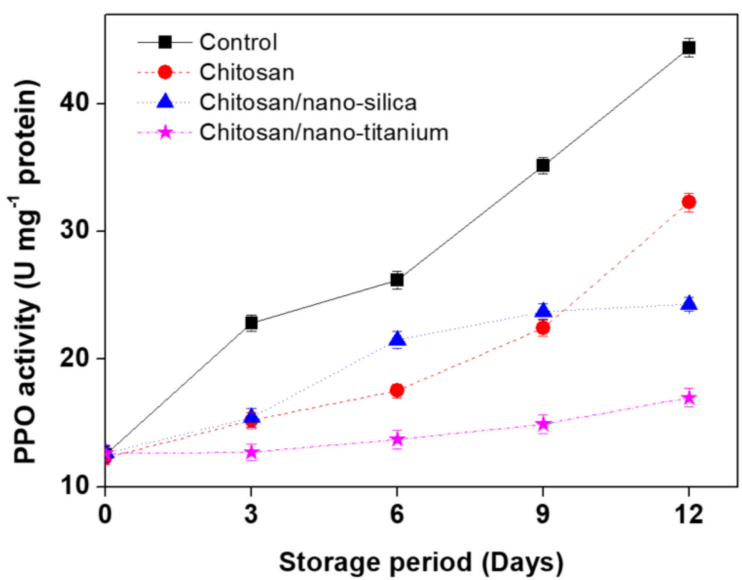

(c)

Figure 4. Effects of nano-films on headspace gas as compositions $\mathrm{O}_{2}$ concentrations (a), $\mathrm{CO}_{2}$ concentrations (b), and PPO activity (c) for white button mushrooms during storage at $4{ }^{\circ} \mathrm{C}$ for 12 days. Data are mean $\pm \mathrm{SD}, n=3$.

\subsection{Microbial Load Contamination}

Difference results for the microbial load contamination of coated mushrooms during storage are presented in Figure 5. It was observed that the microbial load was found to be higher for untreated mushrooms compared to coated white button mushroom samples by various coating treatments in the range of $\sim 6 \log \mathrm{CFU} / \mathrm{g}$. However, the microbial load contamination of coated mushrooms was significantly $(p \leq 0.05)$ high, as mushrooms belong to the funzilla group that is extremely sensitive to microbial contamination attack after harvesting. It was observed that Chitosan/nano-titanium coating treatment significantly $(p \leq 0.05)$ had the best effect on the microbial load contamination (6.12 log CFU/g), followed by Chitosan/nano-silica (6.16 $\log \mathrm{CFU} / \mathrm{g})$. This might be due to the nano-films coating effect which inhibited the microbial contamination on mushroom samples. Chitosan alone reported a slightlyhigher value than for nano-materials treatments (6.17 log CFU/g) as shown by the results in the previous study byKarimirad et al. [22], who reported similar results for the microbial load contamination by using Chitosan nanoparticles on Agaricus bisporus shelf life. 


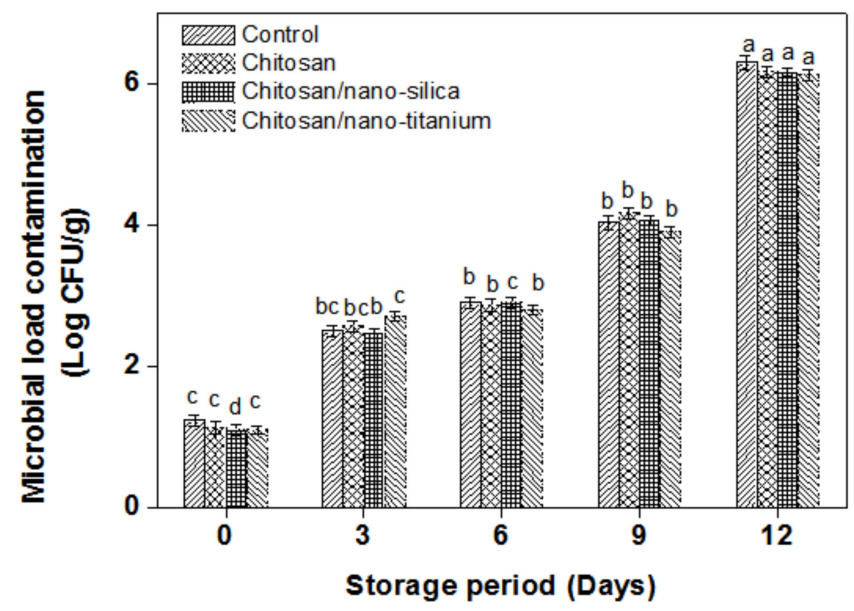

Figure 5. Effects of nano-films on microbial load contamination for white button mushrooms during storage at $4{ }^{\circ} \mathrm{C}$ for 12 days; Data are mean $\pm \mathrm{SD}, n=3$; (a-d) mean significant differences between treatments at $p \leq 0.05$.

\section{Conclusions}

A postharvest application of the nano-films effect on physical properties, mechanical properties, chemical changes, and microbial load contamination of white button mushrooms during storage was effective in delaying senescence. Chitosan/nano-coatings are eco-friendly and efficiently reduced the weight loss, cell membrane damage, inhibited browning, and extended the shelf-life of white button mushrooms bodies. While chitosan alone or along with nano-materialswere found to effective for many of the quality indexes that were considered, the same could not be affirmed for the microbial growth. Extra studies are required for nanotechnology applications to improve mushroom quality for the bio-processing preservation industry.

Author Contributions: Conceptualization, S.R.; methodology, S.R. and E.K.; software, M.H.; validation, A.E.; formal analysis, N.B.; investigation, M.C.; resources, K.V.; data curation, A.I.; writingoriginal draft preparation M.H.; writing-review and editing, M.H. M.C. K.V., and A.I.; visualization, M.H.; supervision, S.R. and N.B.; project administration, S.R.; funding acquisition, S.R. and N.B. All authors have read and agreed to the published version of the manuscript.

Funding: This research received no external funding.

Data Availability Statement: Available upon request from the corresponding author.

Acknowledgments: We acknowledge Taif University Researchers Supporting Project Number (TURSP-2020/140), Taif University, Taif, Saudi Arabia. This research was funded by the Deanship of Scientific Research at Princess Nourah Bint Abdulrahman University through the Fast-track Research Funding Program.

Conflicts of Interest: The authors declared no conflict of interest.

\section{References}

1. Chang, S.-T. Overview of Mushroom Cultivation and Utilization as Functional Foods. In Mushrooms as Functional Foods; Cheung, P.C., Ed.; Wiley and Sons: Hoboken, NJ, USA, 2008; pp. 1-29.

2. Lu, Y.; Zhang, J.; Wang, X.; Lin, Q.; Liu, W.; Xie, X.; Wang, Z.; Guan, W. Effects of UV-C irradiation on the physiological and antioxidant responses of button mushrooms (Agaricus bisporus) during storage. Int. J. Food Sci. Technol. 2016, 51, 1502-1508. [CrossRef]

3. Papoutsis, K.; Grasso, S.; Menon, A.; Brunton, N.P.; Lyng, J.G.; Jacquier, J.-C.; Bhuyan, D.J. Recovery of ergosterol and vitamin D2 from mushroom waste-Potential valorization by food and pharmaceutical industries. Trends Food Sci. Technol. 2020, 99, 351-366. [CrossRef]

4. Rai, R.D.; Arumuganathan, T. Post Harvest Technology of Mushrooms; National Research Centre for Mushroom, Indian Council of Agricultural Research: Chambaghat, India, 2008. 
5. Akbarriad, H.; Kazemeini, S.M.; Shariaty, M.A. Deterioration and some of applied preservation techniques for common mushrooms (Agaricus bisporus, followed by Lentinus edodes, Pleurotus spp.). J. Microbiol. Biotechnol. Food Sci. 2013, 2, $2398-2402$.

6. Ding, Y.; Zhu, Z.; Zhao, J.; Nie, Y.; Zhang, Y.; Sheng, J.; Meng, D.; Mao, H.; Tang, X. Effects of postharvest brassinolide treatment on the metabolism of white button mushroom (Agaricus bisporus) in relation to development of browning during storage. Food Bioprocess. Technol. 2016, 9, 1327-1334. [CrossRef]

7. Hu, Y.-H.; Chen, C.-M.; Xu, L.; Cui, Y.; Yu, X.-Y.; Gao, H.-J.; Wang, Q.; Liu, K.; Shi, Y.; Chen, Q.-X. Postharvest application of 4-methoxy cinnamic acid for extending the shelf life of mushroom (Agaricus bisporus). Postharvest Biol. Technol. 2015, 104, 33-41. [CrossRef]

8. Simón, A.; González-Fandos, E.; Vázquez, M. Effect of washing with citric acid and packaging in modified atmosphere on the sensory and microbiological quality of sliced mushrooms (Agaricus bisporus L.). Food Control. 2010, 21, 851-856. [CrossRef]

9. Hajjar, S.E.; Massantini, R.; Botondi, R.; Kefalas, P.; Mencarelli, F. Influence of high carbon dioxide and low oxygen on the postharvest physiology of fresh truffles. Postharvest Biol. Technol. 2010, 58, 36-41. [CrossRef]

10. Zhang, P.; Sun, H.; Fang, T.; Zhao, Y.; Duan, Y.; Lin, Q. Effects of nitric oxide treatment on flavour compounds and antioxidant enzyme activities of button mushroom (Agaricus bisporus) during storage. Food Qual. Saf. 2020, 4, 135-142. [CrossRef]

11. Villaescusa, R.; Gil, M.I. Quality improvements of Pleurotus mushrooms by modified atmosphere packaging and moisture absorbers. Postharvest Biol. Technol. 2003, 28, 169-179. [CrossRef]

12. Jiang, T.; Zheng, X.; Li, J.; Jing, G.; Cai, L.; Ying, T. Integrated application of nitric oxide and modified atmosphere packaging o improve quality of retention of button mushroom (Agaricus bisporus). Food Chem. 2011, 126, 1693-1699. [CrossRef]

13. Oms-Oliu, G.; Aguiló-Aguayo, I.; Martín-Belloso, O.; Soliva-Fortuny, R. Effects of pulsed light treatments on quality and antioxidant properties of fresh-cut mushrooms (Agaricus bisporus). Postharvest Biol. Technol. 2010, 56, 216-222. [CrossRef]

14. Tao, F.; Zhang, M.; Hangqing, Y.; Jincai, S. Effects of different storage conditions on the chemical and physical properties of white mushrooms after vacuum cooling. J. Food Eng. 2006, 77, 545-549. [CrossRef]

15. Wei, W.; Lv, P.; Xia, Q.; Tan, F.; Sun, F.; Yu, W.; Jia, L.; Cheng, J. Fresh-keeping effects of three types of modified atmosphere packaging of pine-mushrooms. Postharvest Biol. Technol. 2017, 132, 62-70. [CrossRef]

16. Mirshekari, A.; Madani, B.; Golding, J.B. Aloe vera gel treatment delays postharvest browning of white button mushroom (Agaricus bisporus). J. Food Meas. Charact. 2019, 13, 1250-1256. [CrossRef]

17. Jiang, T.; Feng, L.; Li, J. Changes in microbial and postharvest quality of shiitake mushroom (Lentinus edodes) treated with chitosan-glucose complex coating under cold storage. Food Chem. 2012, 131, 780-786. [CrossRef]

18. Liu, J.; Liu, S.; Zhang, X.; Kan, J.; Jin, C. Effect of gallic acid grafted chitosan film packaging on the postharvest quality of white button mushroom (Agaricus bisporus). Postharvest Biol. Technol. 2019, 147, 39-47. [CrossRef]

19. Gholami, R.; Ahmadi, E.; Farris, S. Shelf life extension of white mushrooms (Agaricus bisporus) by low temperatures conditioning, modified atmosphere, and nanocomposite packaging material. Food Packag. Shelf Life 2017, 14, 88-95. [CrossRef]

20. Eldib, R. Application of nano-coating and chitosan combination films on cantaloupe preservation. Pak. J. Biol. Sci. 2020, 23, 1037-1043. [CrossRef]

21. Ctibor, P.; Nevrlá, B.; Neufuss, K.; Petrášek, J.; Sedláček, J. Plasma spray coatings of natural ores from structural, mechanical, thermal, and dielectric viewpoints. Coatings 2019, 10, 3. [CrossRef]

22. Karimirad, R.; Behnamian, M.; Dezhsetan, S. Application of chitosan nanoparticles containing Cuminum cyminum oil as a delivery system for shelf life extension of Agaricus bisporus. LWT 2019, 106, 218-228. [CrossRef]

23. Iqbal, A.; Sun, D.-W.; Allen, P. Prediction of moisture, color and pH in cooked, pre-sliced turkey hams by NIR hyperspectral imaging system. J. Food Eng. 2013, 117, 42-51. [CrossRef]

24. Sultana, S.; Iqbal, A. Hossain comparative study of chitosan extracted from shrimp and crab shell and evaluation of its effect as a preservative on pineapple juice quality. J. Bangladesh Agric. Univ. 2020. [CrossRef]

25. Dhalsamant, K.; Dash, S.K.; Bal, L.M.; Panda, M.K. Effect of perforation mediated MAP on shelf life of mushroom (Volvariella volvacea). Sci. Hortic. 2015, 189, 41-50. [CrossRef]

26. Zhang, L.; Liu, Z.; Wang, X.; Dong, S.; Sun, Y.; Zhao, Z. The properties of chitosan/zein blend film and effect of film on quality of mushroom (Agaricus bisporus). Postharvest Biol. Technol. 2019, 155, 47-56. [CrossRef]

27. Oz, A.T.; Ulukanli, Z.; Bozok, F.; Baktemur, G. The postharvest quality, sensory and shelf life of Agaricus bisporus in active map. J. Food Process. Preserv. 2015, 39, 100-106. [CrossRef]

28. Peng, Y.; Li, T.; Jiang, H.; Gu, Y.; Chen, Q.; Yang, C.; Qi, W.L.; Liu, S.-Q.; Zhang, X. Postharvest biochemical characteristics and ultrastructure of Coprinus comatus. PeerJ 2020, 8, e8508. [CrossRef]

29. Thakur, R.R.; Shahi, N.C.; Mangaraj, S.; Lohani, U.C.; Chand, K. Effect of apple peel based edible coating material on physicochemical properties of button mushrooms (Agaricus bisporus) under ambient condition. Int. J. Chem. Stud. 2020, 8, 2362-2370. [CrossRef]

30. Nasiri, M.; Barzegar, M.; Sahari, M.; Niakousari, M. Application of tragacanth gum impregnated with satureja khuzistanica essential oil as a natural coating for enhancement of postharvest quality and shelf life of button mushroom (Agaricus bisporus). Int. J. Biol. Macromol. 2018, 106, 218-226. [CrossRef]

31. Hosseini, A.; Moradinezhad, F. Effect of short-term high $\mathrm{CO}_{2}$ treatment on quality and shelf life of button mushroom (Agaricus bisporus) at refrigerated storage. Postharvest Biol. Technol. 2018, 1, 37-48. 
32. Rok, E.; Ebtihal, K.; Abeer, E.; Nada, B.; Mahmoud, H. Chitosan, nisin, silicon dioxide nanoparticles coating films effects on blueberry (Vaccinium myrtillus) quality. Coatings 2020, 10, 1-12.

33. Gholami, R.; Ahmadi, E.; Ahmadi, S. Investigating the effect of chitosan, nanopackaging, and modified atmosphere packaging on physical, chemical, and mechanical properties of button mushroom during storage. Food Sci. Nutr. 2020, 8, 224-236. [CrossRef] [PubMed]

34. Eissa, H.A. Effect of chitosan coating on shelf life and quality of fresh-cut mushroom. J. Food Qual. 2007, 30, 623-645. [CrossRef]

35. Khan, Z.U.; Aisikaer, G.; Khan, R.U.; Bu, J.; Jiang, Z.; Ni, Z.; Ying, T. Effects of composite chemical pretreatment on maintaining quality in button mushrooms (Agaricus bisporus) during postharvest storage. Postharvest Biol. Technol. 2014, 95, 36-41. [CrossRef]

36. Liu, J.; Liu, S.; Chen, Y.; Zhang, L.; Kan, J.; Jin, C. Physical, mechanical and antioxidant properties of chitosan films grafted with different hydroxybenzoic acids. Food Hydrocoll. 2017, 71, 176-186. [CrossRef]

37. Singh, S.; Gaikwad, K.K.; Lee, M.; Lee, Y.S. Thermally buffered corrugated packaging for preserving the postharvest freshness of mushrooms (Agaricus bisporus). J. Food Eng. 2018. [CrossRef]

38. Liu, D.; Li, H.; Zhou, G.; Yuan, M.; Qin, Y. Biodegradable poly(lactic-acid)/poly(trimethylene-carbonate)/laponite composite film: Development and application to the packaging of mushrooms (Agaricus bisporus). Polym. Adv. Technol. 2015. [CrossRef]

39. Rachappa, P.; Sudharma, D.C.; Chauhan, O.P.; Patki, P.E.; Nagaraj, R.; Naik, S.; Naik, R. Development and evaluation of white button mushroom based snacks. J. Food Process. Technol. 2020, 1-5. [CrossRef]

40. Ban, Z.; Li, L.; Guan, J.; Feng, J.; Wu, M.; Xu, X.; Li, J. Modified atmosphere packaging (MAP) and coating for improving the preservation of whole and sliced Agaricus bisporus. J. Food Sci. Technol. 2014. [CrossRef]

41. Cliffe-Byrnes, V.; O'Beirne, D. Effects of gas atmosphere and temperature on the respiration rates of whole and sliced mushrooms (Agaricus bisporus)? Implications for film permeability in modified atmosphere packages. J. Food Sci. 2007, 72, E197-E204. [CrossRef] 